\title{
Clinicopathological Study of Neuroendocrine Carcinoma of the Breast
}

\author{
Masahiro Kitada*, Shunsuke Yasuda, Masahiro Abe, Nana Takahashi, Satoshi Okazaki, \\ Kei Ishibashi, Satoshi Hayashi \\ Department of Breast Disease Center, Asahikawa Medical University, Asahikawa, Japan \\ Email: *k1111@asahikawa-med.ac.jp, s-yasuda@asahikawa-med.ac.jp, a080046@al.asahikawa-med.ac.jp, \\ kyokui080026@gmail.com, syugoshin.19851221@gmail.com,kei_dod@hotmail.com, shayashi@asahikawa-med.ac.jp
}

How to cite this paper: Kitada, M., Yasuda, S., Abe, M., Takahashi, N., Okazaki, S., Ishibashi, K. and Hayashi, S. (2017) Clinicopathological Study of Neuroendocrine Carcinoma of the Breast. Journal of Cancer Therapy, 8, 793-799.

https://doi.org/10.4236/jct.2017.88069

Received: July 17, 2017

Accepted: August 19, 2017

Published: August 23, 2017

Copyright () 2017 by authors and Scientific Research Publishing Inc. This work is licensed under the Creative Commons Attribution International License (CC BY 4.0).

http://creativecommons.org/licenses/by/4.0/

\begin{abstract}
Introduction: Neuroendocrine carcinoma (NEC) occurs mostly in the digestive organs, such as the pancreas and gastrointestinal tract, and the lungs. Primary NEC of the breast is a rare entity. There are not many studies on this disease, and this study was carried out in order to know the clinical pathology of this disease. Methods: Of 2354 patients who underwent surgery for breast cancer in our hospital during the period from January 2000 to July 2015, 8 $(0.34 \%)$ were pathologically diagnosed with NEC of the breast. This study is retrospectively registered. Result: The histological types were small cell carcinoma in one patient and invasive ductal carcinoma (IDC) with neuroendocrine differentiation in the remaining 7 . The mean patient age was slightly higher than that of patients with usual IDC. On pathological examination, the NEC tumors were more hormone dependent and often HER2 negative, as compared to usual IDC, though there was no significant difference in nuclear grade. The patients with NEC of the breast showed positivity for neuroendocrine markers on immunohistological staining, and had favorable outcomes. Conclusion: NEC of the breast is rare, and there is no established consensus regarding the pathological significance, prognosis, and treatment method. Further accumulation of cases is necessary.
\end{abstract}

\section{Keywords}

Breast Cancer, Neuroendocrine Carcinoma

\section{Introduction}

Neuroendocrine carcinoma (NEC) occurs mostly in the digestive organs, such as the pancreas and gastrointestinal tract, and the lungs. Primary NEC of the breast is a rare entity. In 2012, the WHO divided NECs into three subtypes: well-diffe- 
rentiated neuroendocrine tumor, small cell carcinoma, and invasive breast carcinoma with neuroendocrine differentiation [1]. In recent years, the number of case reports of NEC of the breast has been increasing. However, there is no established consensus regarding the pathological significance, prognosis, and treatment method because the reported data are still limited and long-term studies are lacking. We reviewed cases with NEC of the breast in our hospital according to the new classification.

\section{Patients and Methods}

Of 2354 patients who underwent surgery for breast cancer in our hospital from January 2000 to July 2015, 8 (0.34\%) were pathologically diagnosed with NEC of the breast. All 8 patients were female. The mean patient age was 60.4 years, slightly higher than that of total patients undergoing breast cancer surgery (58.6 years). Clinicopathological and immunohistological analyses of each cases were performed.

Ethics approval and consent to participate is not applicable. Data sharing not applicable to this article as no datasets were generated or analysed during the current study.

\section{Results}

1) Disease condition, treatment, outcome (Table 1): The mean tumor size was $1.99 \mathrm{~cm}$ (range of tumor size: $0.5-5.0 \mathrm{~cm}$ ). Three cases were positive for lymph node metastasis.

The disease stage was stage I in 4 patients, stage IIA in 3, and stage IIB in one, indicating relatively early stages. Five patients underwent breast-conserving surgery, and the remaining 3 underwent mastectomy. Primary systemic therapy (FEC (fluorouracil $\left(500 \mathrm{mg} / \mathrm{m}^{2}\right)+$ epirubicin $\left(110 \mathrm{mg} / \mathrm{m}^{2}\right)+$ Cyclophosphamide $\left.\left(500 \mathrm{mg} / \mathrm{m}^{2}\right)\right)$ followed by DTX (docetaxel $\left.\left(75 \mathrm{mg} / \mathrm{m}^{2}\right)\right), 8$ cycles) was administered to one patient who had been diagnosed with invasive ductal carcinoma (IDC) on preoperative core needle biopsy, but the effect was judged to be grade 0

Table 1. Characteristics of patients with neuroendocrine carcinoma of the breast.

\begin{tabular}{|c|c|c|c|c|c|c|c|c|}
\hline Case & Age & stage & $\begin{array}{c}\text { Tumor } \\
(\mathrm{cm})\end{array}$ & $\begin{array}{c}\mathrm{N} \text { factor } \\
(\mathrm{P} / \mathrm{D})\end{array}$ & Operation & Adjuvant therapy & $\begin{array}{l}\text { Radiation } \\
\text { therapy }\end{array}$ & Outcome \\
\hline 1 & 85 & IIA & 3.5 & - & $\mathrm{Bp}$ & ET (TAM) & - & $12 \mathrm{Y} 0 \mathrm{M}$ death (other illness) \\
\hline 2 & 75 & IIA & 0.8 & $1 / 7$ & $\mathrm{Bt}+\mathrm{Ax}$ & ET (TAM) & - & $11 \mathrm{Y} 3 \mathrm{M}$ alive \\
\hline 3 & 52 & IIA & 1.5 & $1 / 8$ & $\mathrm{Bp}+\mathrm{Ax}$ & $\mathrm{ET}(\mathrm{TAM} \rightarrow \mathrm{AI})$ & $50 \mathrm{~Gy}$ & 10T0M alive \\
\hline 4 & 45 & I & 1.9 & $0 / 4$ & $\mathrm{Bp}+\mathrm{SN}$ & CT+ET (TAM + LH - THanalogue $)$ & 60 Gy (Boost) & 7Y8M alive \\
\hline 5 & 69 & I & 0.5 & $0 / 5$ & $\mathrm{Bt}+\mathrm{Ax}$ & No adjuvant therapy & - & 4Y11M alive \\
\hline 6 & 75 & I & 1.6 & $0 / 3$ & $\mathrm{Bt}+\mathrm{SN}$ & ET (AI) & - & 4Y7M alive \\
\hline 7 & 36 & IIB & 5.0 & $2 / 27$ & $\mathrm{Bp}+\mathrm{Ax}$ & $\mathrm{CT}+\mathrm{ET}(\mathrm{TAM}+\mathrm{LH}-\mathrm{RH}$ analogue $)$ & 66 Gy (Boost) & 3Y10M alive \\
\hline 8 & 46 & I & 1.2 & $0 / 3$ & $\mathrm{Bp}+\mathrm{SN}$ & ET (TAM + LH - RH analogue) & 60 Gy (Boost) & 2Y9M alive \\
\hline
\end{tabular}

P/D: Positive/Dissection, Bp: breast-conserving surgery, Bt: mastectomy, ET: Endocrine therapy, CT: Chemotherapy (FEC followed by DTX 8cycles) TAM: tamoxifen, AI: Aromatase inhibitor, Boost: Boost irradiation. 
of pathological response grade for chemotherapy. Hormone therapy was administered after postoperative adjuvant chemotherapy (FEC followed by DTX, 8 cycles) to a patient with stage IIB disease. A 5-year hormone therapy regimen was given to 6 subjects, after excluding one patient with triple negative disease. One patient with a small cell carcinoma measuring $0.5 \mathrm{~cm}$ in diameter was not treated because she declined the procedure. Radiation therapy was performed for those who had undergone breast-conserving surgery with 50 - $66 \mathrm{~Gy}$ (boost radiation was additionally performed depending on tumor extension and age). All cases except survival except one case of other illness deaths (case 1), and a median survival time (MST) of 75 months (33 - 144 months), showing favorable outcomes.

2) Histological grade (Table 2): The histological type was small cell carcinoma in one patient and IDC with neuroendocrine differentiation in the remaining 7. The histological grade was of nuclear grading system I in 3 patients, II in 3, and III in 2. Ki-67 expression was measured in cases $4-8$, and the percentage of Ki-67 expression was at least $20 \%$ in these 5 patients. Lymphovascular invasion was observed in only 2 patients. Regarding biological characteristics, the 7 patients with IDC with neuroendocrine differentiation were estrogen receptor (ER)-positive and progesterone receptor ( $\mathrm{PgR}$ )-positive, and one was strongly positive for human epidermal growth factor receptor 2 (HER2). One patient with small cell carcinoma had triple negative disease. Immunological staining revealed the patient with small cell carcinoma to be positive only for neuron specific enolase (NSE), while the other patients were positive for synaptophysin and/or chromogranin. Figures 1-3 show histopathological images of representative cases: case 4, IDC with neuroendocrine differentiation; case 5, small cell carcinoma; and case 7, NEC + mucinous carcinoma.

Table 2. Pathological characteristics of the patients with neuroendocrine carcinoma.

\begin{tabular}{|c|c|c|c|c|c|c|c|c|c|c|}
\hline Case & Pathological diagnosis & Grade & LVI & Ki-67 & ER & PgR & HER2 & Synop. & Chrom. & NSE \\
\hline 1 & $\begin{array}{l}\text { IDC with neuroendocrine } \\
\text { differentiation }\end{array}$ & II & - & - & + & + & $1+$ & + & - & - \\
\hline 2 & $\begin{array}{l}\text { IDC with neuroendocrine } \\
\text { differentiation }\end{array}$ & I & + & - & + & + & $1+$ & + & - & - \\
\hline 3 & $\begin{array}{l}\text { IDC with neuroendocrine } \\
\text { differentiation }\end{array}$ & II & + & - & + & + & - & + & - & - \\
\hline 4 & $\begin{array}{l}\text { IDC with neuroendocrine } \\
\text { differentiation }\end{array}$ & I & - & $24 \%$ & + & + & $1+$ & - & + & - \\
\hline 5 & Small cell carcinoma & III & - & $60 \%$ & - & - & - & - & - & + \\
\hline 6 & $\begin{array}{l}\text { IDC with neuroendocrine } \\
\text { differentiation }\end{array}$ & I & - & $5 \%$ & + & + & $3+$ & + & + & - \\
\hline 7 & $\begin{array}{l}\text { IDC with neuroendocrine } \\
\text { ca+ mucinous ca }\end{array}$ & III & - & $37 \%$ & + & + & $1+$ & + & + & - \\
\hline 8 & $\begin{array}{l}\text { IDC with neuroendocrine } \\
\text { differentiation }\end{array}$ & II & - & $96 \%$ & + & + & - & + & - & - \\
\hline
\end{tabular}

ER: Estrogen Receptor, PgR: Progesterone Receptor, HER2: Human epidermal growth factor receptor, LVI: Lymphovascular invasion Synop.: Synoptophysin, Chrom.: Chromogranin, NSE: Neuron-specific enolase, IDC: Invasive ductal carcinoma. 


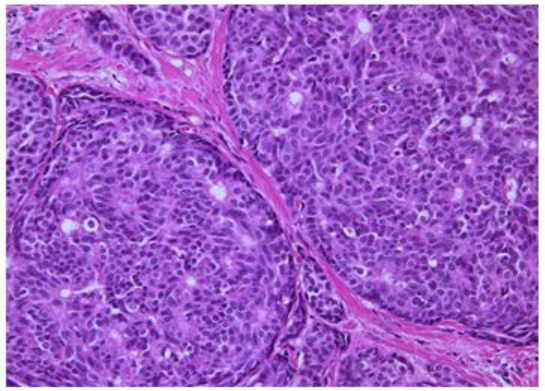

$\mathrm{HE} \times 200$

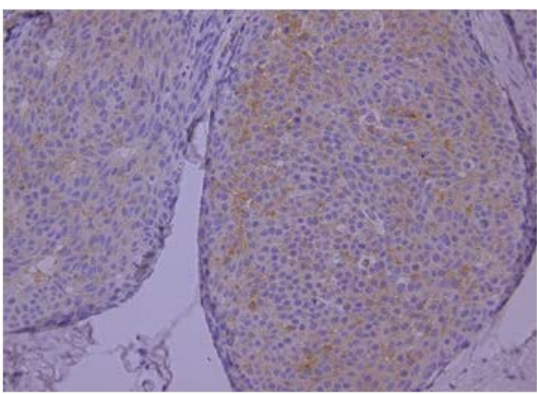

Synoptophysin $\times 200$

Figure 1. Case 4: invasive ductal carcinoma with neuroendocrine differentiation. HE staining (×200): Accept solid cell proliferation. Immunohistological staining $(\times 200)$ : synaptophysin positive.

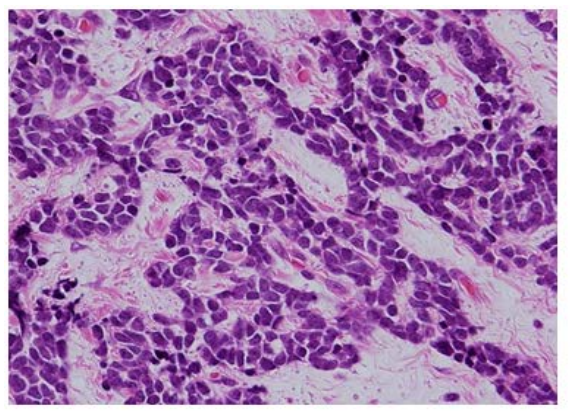

$\mathrm{HE} \times 400$

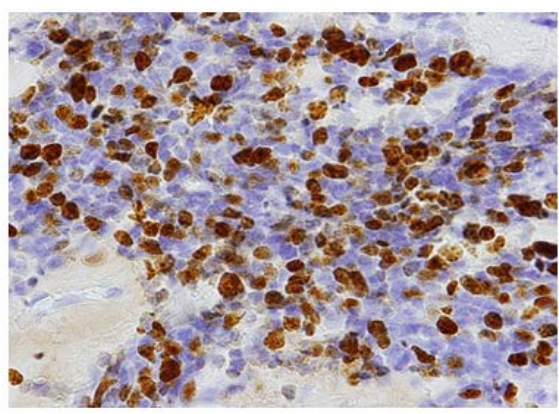

NSE $\times 400$

Figure 2. Case 5: small cell carcinoma. HE staining $(\times 400)$ : Tumor cells with a high N / C and chromatin-rich nucleus grow densely. Neuron-specific enolase (NSE) staining $(\times 400)$ : Immunohistochemical neuroendocrine marker was positive.

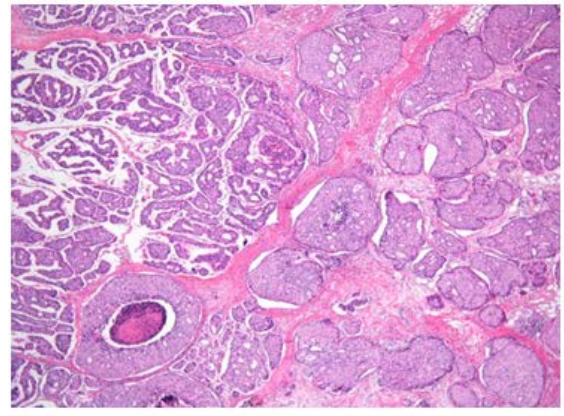

$\mathrm{HE} \times 40$

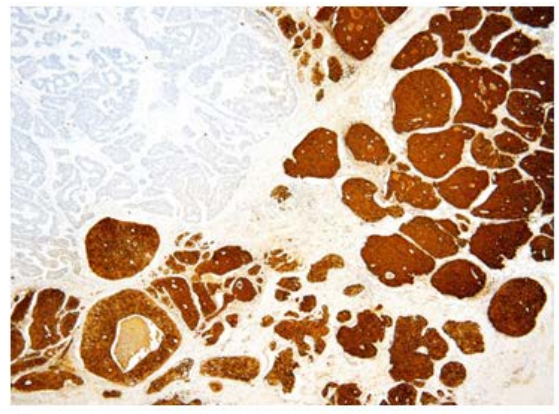

Chromogranin A $\times 40$

Figure 3. Case 6: NEC and mucinous carcinoma coexisted. HE staininig $(\times 40)$ : The NEC part forms (right side) the lamina cribrosa, some with comdedo necrosis. On its left side, cancer cells form papillary agglomerates and are floating in the mucus lake. Myxoid nodules are destroying the surrounding stroma. Immunohistological staining $(\times 40)$ : In the NEC part, Chromogranin A was positive and negative in the mucinous cancer part.

\section{Discussion}

NEC of the breast is a rare entity, comprising $<1 \%$ of all NECs and $<0.1 \%$ of breast carcinomas [2]. It was first reported as carcinoid mammary tumor, and then the tumors with high nuclear grade and high malignancy grade were sepa- 
rately recognized as neuroendocrine tumors of the breast [3]. A major hypothesis regarding pathogenesis is that cancer cells undergo neuroendocrine differentiation [4]. The most common form is IDC of the breast, and a palpable mass is a common clinical presentation, although there are patients in whom cancer is detected based on bloody nipple discharge or who have non-invasive cancer [5] [6]. In the present cases, all tumors had been detected by palpation of a mass.

NECs of the breast are usually seen in mature women, around the seventh or eighth decade of life, and the tumors tend to be larger (measuring $\geq 20 \mathrm{~mm}$ in diameter), higher grade, and more advanced than usual breast cancers. Studies have found both progression free survival and overall survival to be shorter than those of patients with usual IDC [7] [8]. However, in the present study, the patients with NEC had survival rates similar to those of patients with usual IDC and had favorable outcomes (MST of 75 months). According to the literature, the histological characteristics are: expression of neuroendocrine markers (synaptophysin, chromogranin A, CD56, NSE, etc.) in more than 50\% of tumor cells; presence of carcinoid-like structures such as pseudorosettes, cord-like arrangement, small tubules, and alveolar components; and the presence of numerous neuroendocrine granules on micro-morphological observation. Regarding the biological characteristics, most tumors are reportedly hormone dependent and HER2 negative [9]. In the present study, one patient was HER2 positive and the one with small cell carcinoma had triple negative disease.

Reports on treatment of NEC of the breast are limited, and the optimal treatment method and therapeutic effect predictors have not been established. Currently, treatment is conducted according to the regimen for usual IDC. Regarding the effects of chemotherapy, one study demonstrated the use of conventional agents for breast cancer [10], and another found that cisplatin/etoposide followed by paclitaxel/carboplatin was effective [11]. One patient in the present study was diagnosed with IDC, T2N1 on preoperative core needle biopsy and underwent primary systemic therapy (FEC followed by DTX, 8 cycles) but the effect was judged to be grade 0 , raising the possibility that conventional chemotherapy is relatively ineffective for this type of cancer. Further investigation of this issue is needed. In addition, we had planned to treat the patient with small cell carcinoma according to the regimen for treating small cell carcinoma of the lung but she refused.

Reported outcomes are variable. One study found that patients with NEC of the breast reportedly had outcomes similar to those of IDC patients [12]. Another study found that patients with NEC of the breast, especially those with small cell carcinoma, tended to have more advanced disease and poor outcomes [13]. The patients in the present study had favorable outcomes. Further accumulation of cases is needed to clarify disease status. A registration system for this disease, like the registration system for NETs of the digestive organs, is needed to achieve this aim.

\section{Conclusion}

We conducted a clinicopathological study of 8 patients with NEC of the breast. 
These patients were slightly older than those with usual IDC and but there was no significant difference in malignancy grade between the two groups. The NEC tumors were more hormone dependent and were often HER2 negative. The 8 patients with NEC of the breast in the present study had favorable outcomes. Further accumulation of ceases is needed to establish the optimal treatment method for this rare breast cancer.

\section{Consent to Publish}

I have obtained consent to publish from the participant. A copy of the written consent is available for review by the Editor-in Chief of this journal.

\section{Authors Contribution}

MK have operated this case and analyzed all data. SY and NT, SO, KI, SH did the assistant of the operation.

\section{Competing Interests}

I confirm that I have read BioMed Central's guidance on competing interests and have included a statement indicating that none of the authors have any competing interests.

\section{Funding}

There is no funding for this research.

\section{Acknowledgments}

Not applicable, the authors declare that there is no competing interest.

\section{References}

[1] Tan, P.H., Schnitt, S.J., van de Vijver, M.J., Ellis, I.O. and Lakhani, S.R. (2015) Papillary and Neuroendocrine Breast Lesions: The WHO Stance. Histopathology, 66, 761-770. https://doi.org/10.1111/his.12463

[2] Menéndez, P., García, E., Rabadán, L., Pardo, R., Padilla, D. and Villarejo, P. (2012) Primary Neuroendocrine Breast Carcinoma. Clinical Breast Cancer, 12, 300-303. https://doi.org/10.1016/j.clbc.2012.03.001

[3] Cubllia, A.L. and Woodruff, J.M. (1979) Primary Carcinoid of the Breast: A Report of Eight Patisebts. American Journal of Clinical Pathology, 1, 283-292.

[4] Nesland, J.M., Memoli, V.A., Holm, R., Gould, V.E. and Johannessen, J.V. (1985) Breast Carcinomas with Neuroendocrine Differentiation. Ultrastructural Pathology, 8, 225-240. https://doi.org/10.3109/01913128509142155

[5] Kawasaki, T., Mochizuki, K., Yamauchi, H., Yagata, H., Kondo, T., Tsunoda, H., Nakamura, S., Oishi, N., Nakazawa, T., Yamane, T., Inoue, A., Maruyama, T., Inoue, M., Inoue, S., Fujii, H. and Katoh, R. (2012) High Prevalence of Neuroendocrine Carcinoma in Breast Lesions Detected by the Clinical Symptom of Bloody Nipple Discharge. Breast, 21, 652-656. https://doi.org/10.1016/j.breast.2012.01.016

[6] Tsang, W.Y. and Chan, J.K. (1996) Endocrine Ductal Carcinoma in Situ (E-DCIS) of the Breast: A Form of Low-Grade DCIS with Distinctive Clinicopathologic and 
Biologic Characteristics. The American Journal of Surgical Pathology, 20, 921-943. https://doi.org/10.1097/00000478-199608000-00002

[7] Wang, J., Wei, B., Albarracin, C.T., Hu, J., Abraham, S.C. and Wu, Y. (2014) Invasive Neuroendocrine Carcinoma of the Breast: A Population-Based Study from the Surveillance, Epidemiology and End Results (SEER) Database. BMC Cancer, 4, 147. https://doi.org/10.1186/1471-2407-14-147

[8] Zhang, Y., Chen, Z., Bao, Y., Du, Z., Li, Q., Zhao, Y. and Tang, F. (2013) Invasive Neuroendocrine Carcinoma of the Breast: A Prognostic Research of 107 Chinese Patients. Neoplasma, 60, 215-222. https://doi.org/10.4149/neo_2013_029

[9] Yavas, G., Karabagli, P., Araz, M., Yavas, C. and Ata, O. (2015) HER-2 Positive Primary Solid Neuroendocrine Carcinoma of the Breast: A Case Report and Review of the Literature. Breast Cancer, 22, 432-436. https://doi.org/10.1007/s12282-012-0382-x

[10] Nozoe, T., Sueishi, K., Mori, E., Iguchi, T., Egashira, A., Adachi, E., Matsukuma, A. and Ezaki, T. (2011) Primary Neuroendocrine Carcinoma of the Breast: Report of a Case. Surgery Today, 41, 829-931. https://doi.org/10.1007/s00595-010-4351-8

[11] Angarita, F.A., Rodríguez, J.L., Meek, E., Sánchez, J.O., Tawil, M. and Torregrosa, L. (2013) Locally Advanced Primary Neuroendocrine Carcinoma of the Breast: Case Reportand Review of the Literature. World Journal of Surgical Oncology, 11, 128. https://doi.org/10.1186/1477-7819-11-128

[12] Tang, W., Taniguchi, E., Wang, X., Mori, I., Kagiya, T., Yang, Q., Nakamura, Y., Nakamura, M., Yoshimura, G., Sakurai, T. and Kakudo, K. (2002) Loss of Cell Cohesion in Breast Cytology as a Characteristic of Neuroendocrine Carcinoma. Acta Cytologica, 46, 835-840. https://doi.org/10.1159/000327056

[13] Cloyd, J.M., Yang, R.L., Allison, K.H., Norton, J.A., Hernandez-Boussard, T. and Wapnir, I.L. (2014) Impact of Histological Subtype on Long-Term Outcomes of Neuroendocrine Carcinoma of the Breast. Breast Cancer Research and Treatment, 148, 637-644. https://doi.org/10.1007/s10549-014-3207-0

\section{Submit or recommend next manuscript to SCIRP and we will provide best service for you:}

Accepting pre-submission inquiries through Email, Facebook, LinkedIn, Twitter, etc. A wide selection of journals (inclusive of 9 subjects, more than 200 journals) Providing 24-hour high-quality service User-friendly online submission system Fair and swift peer-review system Efficient typesetting and proofreading procedure Display of the result of downloads and visits, as well as the number of cited articles Maximum dissemination of your research work

Submit your manuscript at: http://papersubmission.scirp.org/

Orcontact jct@scirp.org 